\title{
Comparative Virgin Olive Oil and Virgin Coconut Oil of Decubitus Prevention in Patients with Long Rest Beds in Intensive Care Unit (ICU) at Ulin Hospital Banjarmasin
}

\author{
Muhammad Riduansyah, Rian Tasalim, Lukmanul Hakim \\ \{riduansyah@unism.ac.id\}
}

Sari Mulia University, Jl. Scout 2, PemurusAffairs. District. East Banjarmasin, Banjarmasin, South Kalimantan, 70 238, Indonesia

\begin{abstract}
Decubitus is localized tissue damage caused by compression of soft tissue over the protruding bone and long-term external pressure that causes disruption to the blood supply in the depressed area. Find out the comparative picture of virgin olive oil and virgin coconut oil on prevention of pressure sores in patients with long bed rest in the intensive care unit (ICU) of Ulin Hospital Banjarmasin. This study uses a quasi experimental design method with a prepost test model. The sample was all patients with long beds who were at risk for decubitus, who were treated for $\geq 3$ days, physical weakness, decreased consciousness treated in the ICU Ulin Banjarmasin. The results of the study were that (1) the majority of patients had the risk of decubitus in the ICU Ulin Hospital Banjarmasin in late adulthood (36-45 years) (2) The majority of patients at risk of pressure sores in the ICU Ulin Banjarmasin Hospital were male sex ( 3) most respondents before being given virgin olive oil have a score of 12-15 (susceptible to pressure sores). There are differences in decubitus scores before and after virgin coconut oil is given to prevent pressure sores
\end{abstract}

Keywords: Decubitus, Long Rest Beds, Virgin Olive Oil, Virgin Coconut Oil

\section{Introduction}

Decubitus is localized tissue damage caused by compression of soft tissue over the protruding bone and long-term external pressure that causes disruption to the blood supply in the depressed area. This prolonged condition can cause insufficiency of blood flow, tissue ischemia and ultimately can result in cell death. The main causes of pressure sores (pressure sores) are pressure on tissue tolerance that causes insufficiency in blood flow, and ischemia in soft tissue. According to the National Pressure Ulcer Advisory Panel (NPUAP), the decubitus stadium is divided into four stages (Nursalam, 2012).

According to $\mathrm{WHO}$ the incidence of pressure sores throughout the world in intensive care units (ICU) ranges from $1 \%-56 \%$. Furthermore, it was also reported from the prevalence of pressure sores that occurred in ICU from other countries and continents namely $49 \%$ in Europe, $22 \%$ in North America, 50\% in Australia. In Korea specifically in the ICU the incidence of pressure sores increased from $10.5 \%-45 \%$. In Indonesia, the incidence of pressure sores in 
patients treated in ICU reaches 33\%. This figure is very high when compared to the number of pressure sores in Southeast Asia which ranges from 2.1\% -31.3 (Madadi, 2015).

Skin care in an effort to prevent damage can be done by giving coconut oil and olive oil containing various nutrients and good nutrition as a beauty treatment, as a moisturizer that is needed by the skin, because moisture is a good condition to maintain skin cells and make it not old quickly and not cracked. Moisture and elasticity of the skin while expediting the process of skin regeneration, so the skin is not easily dry and wrinkled (Chaerunisa, 2008).

Based on the results of a preliminary study, it was found that patient data from FebruaryApril 2018 in the intensive care unit of Ulin Hospital Banjarmasin found 3 people had pressure sores. 2 people in March and 1 person in April 2018.

\section{Introduction}

Decubitus is localized tissue damage caused by compression of soft tissue over the protruding bone and long-term external pressure that causes disruption to the blood supply in the depressed area. This prolonged condition can cause insufficiency of blood flow, tissue ischemia and ultimately can result in cell death. The main causes of pressure sores (pressure sores) are pressure on tissue tolerance that causes insufficiency in blood flow, and ischemia in soft tissue. According to the National Pressure Ulcer Advisory Panel (NPUAP), the decubitus stadium is divided into four stages (Nursalam, 2012).

According to WHO the incidence of pressure sores throughout the world in intensive care units (ICU) ranges from $1 \%-56 \%$. Furthermore, it was also reported from the prevalence of pressure sores that occurred in ICU from other countries and continents namely $49 \%$ in Europe, $22 \%$ in North America, 50\% in Australia. In Korea specifically in the ICU the incidence of pressure sores increased from $10.5 \%-45 \%$. In Indonesia, the incidence of pressure sores in patients treated in ICU reaches $33 \%$. This figure is very high when compared to the number of pressure sores in Southeast Asia which ranges from 2.1\% -31.3 (Madadi, 2015).

Skin care in an effort to prevent damage can be done by giving coconut oil and olive oil containing various nutrients and good nutrition as a beauty treatment, as a moisturizer that is needed by the skin, because moisture is a good condition to maintain skin cells and make it not old

quickly and not cracked. Moisture and elasticity of the skin while expediting the process of skin regeneration, so the skin is not easily dry and wrinkled (Chaerunisa, 2008).

Based on the results of a preliminary study, it was found that patient data from February-April 2018 in the intensive care unit of Ulin Hospital Banjarmasin found 3 people had pressure sores. 2 people in March and 1 person in April 2018. 


\section{Method}

This study uses an analytical survey research method with a quasi-experimental design approach with a prepost test model. The study took place in the Intensive Care Unit (ICU) of Ulin Hospital Banjarmasin conducted on May 28 - June 11, 2018, starting from data collection to the preparation of results. The method of sampling in this study used purposive sampling technique. The population in this study were all old bed rest patients who were at risk of developing pressure sores, who were treated for hari 3 days, who experienced physical weakness, who had decreased consciousness and composmentis patients with physical weakness. Data collection techniques were carried out by dividing the sample into two groups, namely groups treated with virgin olive oil and groups treated with virgin coconut oil. Then the researchers observed the physical condition of the client during the treatment by applying virgin olive oil and virgin coconut oil in the susceptible to pressure sores, as much as 2 times in the morning and evening. The instrument used in this study was the Northon Scal decubitus assessment scale. This scale was created based on clinical experience that includes five variables. These variables are:
a. Physical condition
b. Mental condition
c. Activity
d. Mobility
e. Incontinence

The maximum score that can be achieved on this scale is 20 . A score of more than 18 means the risk of pressure is still low, 14-18 is a moderate risk, 10-13 is a high risk and less than 10 is included in the very high category. After all observational data has been entered, then the "coding" or "coding" is done, i.e. changing the data in the form of sentences or letters into numerical or numeric data. For example $1=$ yes and $2=$ no.

\section{Results}

\subsection{Age}

Characteristics of Respondents by Age Performed Giving virgin olive oil and virgin coconut oil in the ICU Room Ulin Hospital Banjarmasin.

Table 1. Characteristics of Respondents by Age

\begin{tabular}{|l|l|l|l|}
\hline No & Age & Frequency & Percentage \\
\hline 1 & $26-35$ year & 2 & $20 \%$ \\
\hline 2 & $36-45$ year & 4 & $40 \%$ \\
\hline 3 & $46-55$ year & 2 & $20 \%$ \\
\hline 4 & $>56$ year & 2 & $20 \%$ \\
\hline \multicolumn{2}{c}{ Amount } & 10 & $100 \%$ \\
\hline
\end{tabular}


Based on the above table, it can be seen that from 10 respondents most of the respondents who were given virgin olive oil and virgin coconut oil aged 36-45 years, as many as 4 people (40\%).

\subsection{Gender}

Characteristics of Respondents by Gender Conducted Giving virgin olive oil and virgin coconut oil in ICU Room Ulin Hospital Banjarmasin

Table 2. Characteristics of Respondents by Age

\begin{tabular}{|l|l|l|l|}
\hline No & Gender & Frequency & Percentage \\
\hline 1 & Man & 6 & $60 \%$ \\
\hline 2 & Woman & 4 & $40 \%$ \\
\hline \multicolumn{2}{|l|}{ Amount } & 10 & $100 \%$ \\
\hline
\end{tabular}

\subsection{Virgin olive oil and virgin coconut oil}

Based on the above table, it can be seen that of the 10 respondents most respondents who were given the administration of virgin olive oil and virgin coconut oil at the Ulin Hospital Banjarmasin Banjarmasin were 6 men (60\%).

a. Distribution of virgin olive oil on the prevention of pressure sores in patients with prolonged bed rest in the Intensive Care Unit (ICU) Ulin District Hospital Banjarmasin

Table 3. Distribution of virgin olive oil on the prevention

\begin{tabular}{|l|l|l|l|}
\hline No & $\begin{array}{l}\text { Skore } \\
\text { Dekubitus }\end{array}$ & $\begin{array}{l}\text { Frequency \& } \\
\text { Percentage } \\
(\%) \text { Pre }\end{array}$ & $\begin{array}{l}\text { Frequency \& } \\
\text { Percentage (\%) } \\
\text { post }\end{array}$ \\
\hline 1 & $\begin{array}{l}\text { There is no } \\
\text { risk of } \\
\text { decubitus } \\
(16-20)\end{array}$ & $0(0 \%)$ & $1(20 \%)$ \\
\hline 2 & $\begin{array}{l}\text { Prone to } \\
\text { decubitus } \\
(12-15)\end{array}$ & $3(60 \%)$ & $3(60 \%)$ \\
\hline 3 & High risk & $2(40 \%)$ & $1(20 \%)$ \\
\hline
\end{tabular}




\begin{tabular}{|l|l|l|l|}
\hline & $\begin{array}{l}\text { decubitus } \\
(<12)\end{array}$ & & \\
\hline Amount & $5(100 \%)$ & $5(100 \%)$ \\
\hline
\end{tabular}

Based on the above table, it can be seen that from 10 respondents who were given virgin olive oil as many as 50 people. Most of the respondents before giving virgin olive oil had a score of $12-15$ (susceptible to pressure sores) as many as 3 people (60\%), 2 people $(40 \%)$ had a score $<12$ (high risk of pressure sores), and after giving virgin olive oil which has a score of 12-15 (susceptible to pressure sores) there is no permanent change in 3 people $(60 \%)$, who has a score of 16-20 (no risk of pressure sores) that is 1 person $(20 \%)$ and who has a score $<12$ ( high risk of developing pressure sores 1 person (20\%).

b. Distribution of virgin coconut oil on the prevention of pressure sores in patients with prolonged bed rest in the Intensive Care Unit (ICU) of Ulin Hospital Banjarmasin

Table 4. Distribution of virgin olive oil on the prevention

\begin{tabular}{|l|l|l|l|}
\hline No & $\begin{array}{l}\text { Skore } \\
\text { Dekubitus }\end{array}$ & $\begin{array}{l}\text { Frequency \& } \\
\text { Percentage } \\
(\%) \text { Pre }\end{array}$ & $\begin{array}{l}\text { Frequency \& } \\
\text { Percentage (\%) } \\
\text { post }\end{array}$ \\
\hline 1 & $\begin{array}{l}\text { There is no } \\
\text { risk of } \\
\text { decubitus } \\
(16-20)\end{array}$ & $0(0 \%)$ & $0(0 \%)$ \\
\hline 2 & $\begin{array}{l}\text { Prone to } \\
\text { decubitus } \\
(12-15)\end{array}$ & $0(0 \%)$ & $5(100 \%)$ \\
\hline 3 & $\begin{array}{l}\text { High risk } \\
\text { dekubitus } \\
(<12)\end{array}$ & $5(100 \%)$ & $0(0 \%)$ \\
\hline
\end{tabular}

Based on the table above, it can be seen that from 10 respondents who were given virgin coconut oil as many as 5 people. Most respondents before being given virgin 
coconut oil had a score of $12-15$ (susceptible to pressure sores) namely 3 people (60\%), who had a score $<12$ (high risk of developing pressure sores) namely 2 people (40\%) and after giving virgin coconut oil all respondents had a score of 12-15 (susceptible to pressure sores) as many as 5 people (100\%).

c. Comparative analysis of virgin olive oil and virgin coconut oil on the prevention of pressure sores in patients with prolonged bed rest in the Intensive Care Unit (ICU) of Ulin Hospital Banjarmasin.

Table 5. Comparative analysis of virgin olive oil and virgin coconut oil

\begin{tabular}{|c|c|c|c|c|c|c|c|c|}
\hline \multirow[t]{2}{*}{ No } & \multirow[t]{2}{*}{ Pemberian } & \multicolumn{2}{|c|}{$\begin{array}{l}16 \\
- \\
20\end{array}$} & \multicolumn{2}{|c|}{$12-15$} & \multicolumn{2}{|l|}{$<12$} & $\begin{array}{l}\mathbf{P} \\
\text { Value }\end{array}$ \\
\hline & & $\mathrm{N}$ & $\%$ & $\mathrm{~N}$ & $\%$ & $\mathrm{~N}$ & $\%$ & \\
\hline \multirow[t]{2}{*}{1} & $\begin{array}{l}\text { Virgin olive } \\
\text { oil } \\
\text { (Pre) }\end{array}$ & 0 & 0 & 2 & 40 & 2 & 40 & \multirow[t]{2}{*}{$\begin{array}{l}0.17 \\
8\end{array}$} \\
\hline & $\begin{array}{l}\text { Virgin olive } \\
\text { oil } \\
\text { (Post) }\end{array}$ & 1 & $\begin{array}{l}2 \\
0\end{array}$ & 3 & 60 & 1 & 20 & \\
\hline \multirow[b]{2}{*}{2} & $\begin{array}{l}\text { Virgin } \\
\text { coconut oil } \\
\text { (Pre) }\end{array}$ & 0 & 0 & 0 & 0 & 5 & $\begin{array}{l}10 \\
0\end{array}$ & \multirow[b]{2}{*}{$\begin{array}{l}0.00 \\
0\end{array}$} \\
\hline & $\begin{array}{l}\text { Virgin } \\
\text { coconut oil } \\
\text { (Pre) }\end{array}$ & 0 & 0 & 5 & 100 & 0 & 0 & \\
\hline
\end{tabular}

Based on the table above, it can be concluded that the virgin olive oil has a value of $p=$ 0.178 meaning that there is no difference before and after giving virgin olive oil. Virgin coconut oil has a value of $p=0,000$ which means there are differences before and after giving virgin coconut oil.

\section{Discussion}

\subsection{Respondents by Age}

Based on the results of the study that the majority of patients with risk of decubitus in the ICU Ulin Hospital Banjarmasin in late adulthood (36-45 years) as many as 4 people (40\%) early adults 2 people (20\%), the elderly elderly 2 people (20\%) and late elderly 2 people (20\%). 
This study is also in line with Reddy's research (2011) which says that late adults and the elderly have great potential to experience pressure sores due to skin changes due to age, the tendency of older people who often lie in one position therefore immobilization will expedite the risk of decubitus.

\subsection{Respondents Based on Gender}

Based on the results of the study that the majority of patients at risk of pressure sores in the ICU Ulin Hospital Banjarmasin in the male gender 6 people $(60 \%)$ and women 4 people (40\%). In line with zulaikha's research (2015) which stated that the sex of the most respondents was male as many as 42 people $(63.6 \%)$. But according to Suriadi (2004) gender is not a risk factor for pressure sores. There are several important hormonal factors that are likely to play a role in explaining the differences between men and women, namely women are protected by the hormone estrogen before menopause.

\subsection{Comparison of Virgin Olive Oil and Virgin Coconut Oil Against Prevention of Decubitus in Patients with Old Bedrests}

Based on the results of the study most of the respondents before administering virgin olive oil had a score of $12-15$ (susceptible to pressure sores) as many as 3 people $(60 \%)$, 2 people (40\%) had a score <12 (high risk of pressure sores), and after virgin olive oil was administered which had a score of 12-15 (susceptible to pressure sores) there were no permanent changes in 3 people $(60 \%)$, who had a score of 16-20 (no risk of pressure sores) namely 1 person $(20 \%)$ and who had a score $<12$ (high risk of pressure sores) 1 person $(20 \%)$. Based on the results of the study most of the respondents before being given virgin coconut oil had a score of $12-15$ (susceptible to pressure sores) namely 3 people $(60 \%)$, who had a score $<12$ (high risk of pressure sores) namely 2 people $(40 \%)$ and after it was done giving virgin coconut oil all respondents had a score of 12-15 (susceptible to pressure sores) as many as 5 people $(100 \%)$.

Based on research conducted, it can be concluded that there are differences before and after administration of virgin coconut oil to prevent pressure sores by applying virgin coconut oil 2 times a day in areas susceptible to pressure sores, because one of them contains virgin coconut oil which has antioxidant which functions to prevent aging premature, vitality of the body as well as maintaining skin moisture, because one of the causes of pressure sores / pressure sores is moisture, by keeping skin moisture applying virgin coconut oil will make the skin moist so as to prevent pressure sores / pressure sores. This is in line with the research of Handayani, et al (2011) Prevention of pressure sores through massage using virgin coconut oil and preventive care (left-right sloping every 2 hours, bathing $2 \mathrm{x}$ a day), effective in preventing the occurrence of grade I pressure sores on clients compared with clients treated without VCO.

\section{Conclusions}

Both the hospital and educational institutions can collaborate helps in the administration of virgin olive oil and virgin coconut oil to prevent decubitus. 


\section{References}

[1] Chaerunnisa, Revealing the Miracle of Olive Oil, Seen June 11, 2018, http://lifestyle.okezone.com/read/2008/02/17/27/84228/Making the Magic-of-Oil-Olives. (2008).

[2] Darmoyuwono, W. Healthy Lifestyle With Virgin Coconut Oil. Jakarta: PT. Index. Thing. 2. 9. 47. (2006).

[3] Hapsari, N. Making Virgin Coconut Oil (VCO) with the Centrifugation Method. Chemical Engineering Department, Faculty of Industrial Technology UPN Veteran East Java. (2013).

[4] Handayani S, Dewi DI, Riau. Prevention of Pressure Sores Through Massage Using Virgin Coconut Oil. Indonesian Nursing Journal. 14 (3). 141-148. (2011).

[5] Notoatmodjo, S. Qualitative and Quantitative Research Methodologies in the Field of Health. Yogayakarta: Nuha Medika. (2012).

[6] Nursalam. The Concept and Application of Research Methodology and Nursing Science. Jakarta: Salemba Medika. (2013).

[7] Potter \& Perry. Nursing Fundamental Textbooks Concepts. Processes and Practices. Jakarta: EGC. (2005).

[8] Rowe, R.C., Paul, J.S dan Paul, J.W. Handbook of pharmaceutical excipient. London: Chicago Pharmaceutical Press. (2003).

[9] Rajamohan, T., \& Kevin, K.G. Effect of topical application of virgin coconut oil on skin components and antioxidant status during dermal wound healing in young rats. Journal of Pharmacology \& Bhiophysical Research. 23 (6): 1-20. (2010).

[10] Sugiyono. Qualitative and Quantitative Research Methodologies in the Field of Health. Yogayakarta: Nuha Medika. (2013).

[11] Sukardi. concepts and practice of writing nursing research, Edition 2. Yogyakarta. Graha science. (2008).

[12] Yolanda, Oktaria and Utomo, Wasisto. Effectiveness of olive oil on plessure ulcers with old bed rest. University of Riau Journal. Riau. (2013). 